Egyptian Poultry Science Journal

http://www.epsaegypt.com

ISSN: 1110-5623 (Print) - 2090-0570 (On line)

\title{
ROLE OF SPRAYING HATCHING EGGS WITH NATURAL DISINFECTANTS ON HATCHING CHARACTERISTICS AND EGGSHELL BACTERIAL COUNTS
}

\author{
E.H.A.Shahein ${ }^{\mathbf{1}}$ and Eman K. Sedeek ${ }^{\mathbf{2}}$ \\ ${ }^{1}$ Anim. Prod. Res. Inst., Agric. Res. Center, Egypt \\ ${ }^{2}$ Anim. Health Res. Inst., Alex. Provincial Lab., Agric. Res. Center, Egypt
}

Received: 16/01/2014

Accepted: 24/02/2014

\begin{abstract}
The present experiment was carried out to study the role of spraying hatching eggs with natural disinfectants on hatching characteristics and eggshell bacterial counts. Seven hundred females with seventy males from Gimmizah chickens aged $45 \mathrm{wk}$ were housed in floor pens. Hatching eggs produced from Gimmizah hens were collected four times a day and subjected to disinfection within the first four hours after laying. Two thousand and one hundred hatching eggs were divided into seven treatment groups. Eggs of first and second groups were sprayed by propoplis $7 \%$ and $14 \%$, respectively. The third and the fourth groups were sprayed by thyme oil $0.5 \%$ and $0.7 \%$, respectively. The fifth group was sprayed by ethyl alcohol $70 \%$, the sixth group was subjected to formaldehyde fumigation for 20 minutes $(119.8 \mathrm{ml}$ formalin and $59.9 \mathrm{gm}$ potassium permanganate $12.83 \mathrm{~m}^{3}$ ) and the seventh eggs group was considered as control (untreated).

Results obtained are summarized as follows:-

1- Spraying the eggs with propolis $14 \%$ and thyme oil $(0.5$ and $0.7 \%)$ significantly decreased egg weight loss percentage during the setting phase compared with the other experimental disinfectants, fumigation and control.

2- Highest significant percentages of embryonic mortalities during the whole incubation period (O-pipping) were observed for eggs disinfected with ethyl alcohol and control untreated groups, whereas the lowest ones were detected for eggs disinfected with both concentrations of propolis (7 and 14\%) and formaldehyde fumigation.

3- Hatchability percentages were significantly increased for both propolis concentrations and formaldehyde fumigation.

4- The heaviest chick body weight at hatch and at pull out were recorded for chicks produced from group treated with propolis 14\% compared with those produced from other egg treatments.
\end{abstract}

Key Words: Natural disinfectants, bacterial count, hatch time, chick weight, hatchability.

Corresponding author: dr_sayedshahen00@yahoo.com 
5- The shortest range between maximum and minimum time of hatch was recorded for propolis $14 \%$ ( $29.0 \mathrm{hrs})$ while the longest range was recorded for control group (34.0hrs).

6- The best significant reduction results for total bacterial, total Coliform and total

Staphylococcus counts on eggshell surface had been realized through using propolis and formaldehyde fumigation, while fumigation did not possess the residual effect on eggshell during storage as observed for propolis.

It coud be concluded that spraying propolis $14 \%$ as disinfectant for hatching eggs could be recommended as natural and safe disinfectant for realizing the best results of hatching success, body weight at hatch and confined hatched chicks in shortest time and diminishing the bacterial load on the eggshell.

\section{INTRODUCTION}

The ideal environment for the embryo development is the same needed for microorganism multiplication. Therefore, contaminated eggs will disseminate microorganisms in incubators and hatchers and in turn will reduce hatchability and produce low quality chicks (Bramwell, 2000).The practices for keeping the eggs sanitary quality require frequent collection and mainly adequate cleaning and disinfection. Therefore, the eggs must be as quick as possible thoroughly disinfected after being laid, by adequate methods and compounds (Sesti, 2005).

Eventually, bacteria penetrate the shell and infect the embryo, causing losses in hatchability, therefore an effective hatchery sanitation program is critical to achieve a high level of hatchability and ensure the production of high quality chicks (Sacco et al., 1989).

Fumigation with formaldehyde has been the method used by most producers to achieve that, but the implication of the control of substances harmful hazardous to health legislating is causing many procedures sanitizing techniques (Sparks and Burgess, 1993). Although this method is efficient in keeping incubation with low levels of contamination with high levels of hatchability, it is important to highlight that formaldehyde is toxic, not only to birds but also to human beings (Hayretda and Kolankaya, 2008).

Propolis is a sticky gummy resinous substance collected by worker honeybee (Apis melifera) from young shoots and buds of certain trees and shrubs and it has strong antibacterial, antifungal, and antiviral properties (Krell, 1996; Bankova et al., 2000). In addition, propolis has considerable antibiotic effects on Salmonella, Staphyloccus aureus, P. vulgaris, and Escherichia coli (Powers, 1964). Copur et al. (2008) stated that covering table eggs with propolis improved interior egg quality during storage. Propolis constituents of the Egyptian propolis are phenolic acid esters $(72.7 \%)$; phenolic acid (1.1\%); aliphatic acids (2.4\%); dihydrochalcones $(6.5 \%)$; chalcones $(1.7 \%)$; flavanones(1.9\%); flavones (4.6\%) and tetrahydrofuran derivatives $(0.7 \%)$ (Abd El-Hady, and Hegazi, 1994).

Thymus species are commonly used as herbal tea, flavoring agents (condiment and spice) and medicinal plants and recent studies have shown that Thymus species have strong antibacterial, antiviral, spasmolytic and antioxidant activities (Sáez and Stahl-Biskup, 2002).

Recent studies have shown that thyme has strong antibacterial, antiviral, spasmolytic and antioxidant activities (Stahl-Biskup and Saez, 2002). Thyme showed broad antibacterial activity by inhibiting the growth of both gram-positive 
and gram-negative bacteria. However, gram positive bacteria Clostridium botulinum and Clostridium perfringens appeared to be more sensitive than the gram-negative organisms (Nevas et al., 2004). In vitro antibacterial study of thyme showed greatest inhibition against Aeromonas hydrophila compared to other psycrotrophic food-borne bacteria such as Aeromonas hydrophila, Listeria monocytogenes and Yersinia enterocolitica (Fabio et al, 2003).

Using ethyl alcohol $70 \%$ in hatching eggs had a lower microbial activity compared with those for control group after 1 day of storage period (Aygun and Sert 2013).

Egg weight loss is an important parameter for incubation. It has been used to estimate vital gas exchange (Paganelli et al., 1978; Rahn et al., 1979) and has been correlated with the rate of embryonic metabolism and development (Burton and Tullett, 1983). The relationship between egg weight loss and survival of the embryo may be related to the difference in the ability of embryos to regulate their water contents and eggshell conductance (Peebles and Brake, 1986; Davis and Ackerman, 1987). Proper cleaning of hatching eggs is important to reduce embryonic mortality (Kuo et al., 1996). Increasing survivability of an embryo could be done by keeping the egg surface free of contaminants (Kuo et al., 1997). An effective hatchery sanitation program is critical to achieve a high level of hatchability and ensure the production of high quality chicks. Several scientists have concluded that the conductance of the eggshell is inversely related to the length of the incubation period for eggs of a known weight (Hoyt, 1980). Reinhart and Hurnik (1984) stated that the main factor causing dehydration after chicks hatched was the relative humidity of the machine and the length of time from completing the hatching process to the removal from the hatcher (pulling). Wyatt et al. (1985) reported that the longer stay for chicks in the hatcher resulted in more dehydration and in turn high mortality of chicks.

This experiment was performed to investigate the role of spraying hatching eggs with natural disinfectants and fumigation in reducing the bacterial load on eggshell surface and gain a new insight on the relation between these disinfectants and fumigation with the embryonic development and hatching process.

\section{MATERIALS AND METHODS}

The present experiment was carried out at El-Sabahia Poultry Research Station, Animal Production Research Institute and Animal Health Research Institute, Alexandria Provincial Lab., Agricultural Research Centre, Egypt. Seven hundred females with seventy males from Gimmizah chickens aged 45wk were housed in floor pens. Hatching eggs produced from Gimmizah hens were collected four times a day and subjected to disinfection within the first four hours after laying. Extra and small hatched eggs, misshapen and cracked eggs were excluded. Two thousand and one hundred hatching eggs were divided into 7 groups, each one contained 300 eggs and replicated three times in three trays. Each egg group represented disinfection treatment from natural sources, ethyl alcohol and formaldehyde fumigation compared to untreated group (control) as demonstrated in Table 1. Also, the disinfectants were diluted with distilled water or ethyl alcohol as described in Table 1 and sprayed to cover the whole surface area of eggshells.

Eggs for fumigation group were subjected to formaldehyde fumigation inside separate incubator for 20 minutes $(119.8 \mathrm{ml}$ formalin $+59.9 \mathrm{~g}$ potassium permanganate $/ 2.83 \mathrm{~m}^{3}$ ) according to the method described by Yildirim et al. (2003).After disinfectant application, the eggs were allowed to air drying at room temperature by electric fans and stored for no longer than 4 days before setting in the incubator. 
Table (1): Disinfectant concentrations and formaldehyde fumigation

\begin{tabular}{|c|c|c|}
\hline Treatment used & Concentrations & Applications \\
\hline Propolis $14 \%$ & $\begin{array}{l}\text { Propolis solution was prepared by } \\
\text { mixing } 860 \mathrm{ml} \text { of } 70 \% \text { ethyl alcohol } \\
\text { and } 140 \mathrm{gm} \text { of propolis }\end{array}$ & Spray \\
\hline Propolis $7 \%$ & $\begin{array}{l}\text { Propolis solution was prepared by } \\
\text { mixing } 930 \mathrm{ml} \text { of } 70 \% \text { ethyl alcohol } \\
\text { and } 70 \mathrm{gm} \text { of propolis }\end{array}$ & Spray \\
\hline Thyme oil $0.5 \%$ & $\begin{array}{l}125 \mathrm{ml} \text { of ethyl alcohol } 70 \%+0.5 \% \\
\text { thyme oil per litre solution }\end{array}$ & Spray \\
\hline Thyme oil $0.7 \%$ & $\begin{array}{l}125 \mathrm{ml} \text { of ethyl alcohol } 70 \%+0.7 \% \\
\text { thyme oil per litre solution }\end{array}$ & Spray \\
\hline Ethyl alcohol $70 \%$ & Ethyl alcohol $70 \%$ & Spray \\
\hline $\begin{array}{l}\text { Formaldehyde fumigation } \\
\text { Control }\end{array}$ & $\begin{array}{l}119.8 \mathrm{ml} \text { formalin }+59.9 \mathrm{gm} \text { potassium } \\
\text { permanganate } / 2.83 \mathrm{~m}^{3} \text { for } 20 \text { minutes } \\
\text { untreated }\end{array}$ & Fumigation \\
\hline
\end{tabular}

\section{Incubation and its Parameters:}

Eggs were numbered consecutively and weighed before setting in Egyptianmade incubator operated at $37.5^{\circ} \mathrm{C}$ and $55 \%$ relative humidity. The time of setting eggs in the incubator was recorded for each trial to obtain the exact hatch time in hours and considered as zero hour of the experiment. All eggs were set and distributed randomly at different places in the same trolley of the incubator to reduce possible position effects. On the $18^{\text {th }}$ day of incubation, the eggs were transferred singly into pedigree hatching nests and then placed into the hatchery for the remainder of the incubation period at $37.2^{\circ} \mathrm{C}$ and $65 \%$ relative humidity.

\section{Egg Weight Loss:}

All eggs were individually weighed again during incubation on $5^{\text {th }}, 10^{\text {th }}, 18^{\text {th }}$ days and at first signs of pipping in order to obtain egg weight loss percentages for each incubation period.

\section{Embryonic Death:}

Eggs that failed to hatch and having full opportunity to hatch were broken out then examined macroscopically to estimate the embryonic development and assigned according to their times of death by day as possible. Embryonic mortality was recorded every day of incubation and classified into three periods $(0-6,7-15$ and 16-pipping day) and the percentage was expressed as percentage of fertile eggs.

\section{Hatchability:}

Hatchability was expressed as percentages of total and fertile eggs. All percentages data of hatchability were subjected to arcsine square root percentage transformation prior to analysis.

\section{Hatch Time, Chick Weight and Chick Weight Loss:}

Beginning at $468 \mathrm{hrs}$ of incubation and at $6 \mathrm{hrs}$ intervals thereafter the hatchery was opened. Chicks that had fully emerged from eggs were removed, wing banded, weighed to the nearest $0.1 \mathrm{gm}$ and recorded as chick body weight at hatch then placed again to the incubator after recording the time of hatch. Hatch time and body weight at hatch were monitored every 6 hours after the hatch of first chick. The chicks were left in the incubator until servicing time (termination of incubation). All chicks were weighed again at the time of removal from the hatchery at $503 \mathrm{hrs}$ and recorded as chick weight at pull out. 
Chick body weight loss percentage during incubation was calculated as follows:

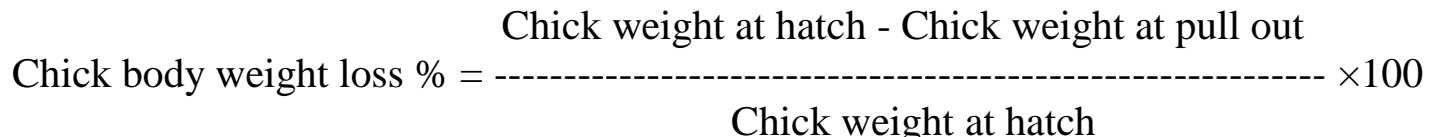

Range of hatch time was recorded as maximum record of hatch time - minimum record

\section{Bacteriological examination:}

Forty eggs per each treatment were taken for bacteriological analysis at laying day and after storage for four days. Each egg was placed immediately in sterile bags containing $10 \mathrm{~mL}$ of sterile, phosphate buffered saline (PBS) ( $\mathrm{pH}$ 7.2). A wholeegg washing technique was used to recover the shell-associated microorganisms for estimating the total viable bacterial count (TBC), total Coliform count (TCC) and total Staphylococcus count (TSC) spp. Count by using plate counting agar (PCA), MacConkey agar medium and Baired Parker agar (BPA) (Difco, USA), respectively. Serial dilutions were made in PBS and then were inoculated into sterile petri plates (Gentry and Quarles, 1972; Jones et al., 2002). The plates were packed and incubated at $37^{\circ} \mathrm{C}$ for $24 \mathrm{hrs}$ at the end of incubation, the plates were removed and colonies were counted and multiplied by the dilution factor. Colonies were measured as cfu/egg (Özçelik, 1992).

\section{1- Total bacterial count:}

Total bacterial count was obtained on plate counting agar and carried out according to standard methods of BAM. (2005).

\section{2- Total Coliform count:}

Dilutions made for TBC were pourplated on MacConkey agar (Oxoid Ltd., Hampshire, England); typical pink colonies for TCC were counted after $24 \mathrm{hrs}$ of incubation at $37^{\circ} \mathrm{C}$. Confirmation of E. coli was carried out by indole, methyl red, voges- proskauar and citrate (IMVIC) tests.

\section{3- Total Staphylococcus count:}

Dilutions made for TBC were pour-plated on Baired Parker agar (BPA) (Difco, USA). Typical colonies were counted after $24 \mathrm{hrs}$ of incubation at $37^{\circ} \mathrm{C}$.Suspected Staphylococcus spp colonies were tested for coagulase activity and confirmed by other biochemical reactions.

\section{Statistical Analysis:}

Statistical analysis was conducted using SAS program (SAS, 1998) software and following model was used:

$\mathrm{Yij}=\mathrm{M}+\mathrm{Li}+\mathrm{eij}$

\section{Where:}

Yij $=$ The observation record

$\mathrm{M}=$ The overall mean,

$\mathrm{Li}=$ The effect of disinfection, $\mathrm{i}=1-7$ and eij $=$ The random error.

Bacterial counts were statistically analysed. Mean differences were separated by Duncan New Multiple range test (Duncan's, 1955).

\section{RESULTS AND DISCUSSION}

Effects of hatching egg disinfection on egg weight loss percentage of fertile eggs during different incubation intervals are shown in Table 2. Eggs disinfected with propolis $14 \%$ and thyme oil $0.7 \%$ represented the lowest significant percentage of egg weight loss compared to control untreated groups during the first five days of incubation. The same trend of decrease of egg weight loss percentage was observed for the same mentioned groups during the setting phase of incubation (zero -18 days) besides thyme oil $0.5 \%$. Also, 
all disinfection treatments had no significant influence on egg weight loss percentage throughout $(6-10$ and $11-18$ days).The rates of egg weight loss varied between 9.79 and $11.90 \%$ throughout the setting phase of incubation. It is obvious from data of this table that treatment the eggs with propolis $14 \%$ and thyme oil $0.7 \%$ decreased egg weight loss percentage compared with other egg treatment. This result could be explained on the light of occluded egg pores due to the oily nature of these disinfectants which diminished the evaporation of water vapour and egg weight loss percentage. Egg weight loss is an important factor for affecting the hatching success, in many domesticated species and the amount of egg weight loss is around $12-14 \%$ of initial egg mass by pipping time (Tullett, 1990; Soliman, 2000).

The changeable results of egg weight loss percentage due to egg treatment with disinfectants are reasonable since the disinfectants might affect the cuticle layers and shell porosity. This assumption is confirmed by Brake and Sheldon (1990) who reported that any alteration or removal of the cuticle by sanitizers may have a significant impact on egg weight loss and hatchability. Also, Geng and Wang (1990) reported that too-fast moisture loss was disadvantageous for the normal embryonic development. Yet the literature on the possible deleterious effects of fumigation on the cuticle is limited (Cadirci, 2009). Also, Aygun et al. (2012) supported the results of the present study and confirmed that eggs sprayed with propolis had lower egg weight loss than those from other groups.

Effects of egg disinfection on embryonic mortality percentage during different stages of incubation are summarized in Table 3. Highest significant differences $(\mathrm{P} \leq 0.05)$ of embryonic mortality percentages during early stage of incubation (0 -6 days) were observed in eggs of control group (6.20\%) followed by ethyl alcohol $70 \%$ (5.13\%) compared to those for other experimental groups. While, the lowest ones in the same period were detected for propolis 14\%, propolis $7 \%$, thyme oil $0.7 \%$ and formaldehyde fumigation. Moreover, during the mid stage of incubation ( 7 - 15days), ethyl alcohol $70 \%$ and control untreated groups represented the highest percentages of embryonic mortality and the lowest ones were recorded for both concentrations of propolis besides formaldehyde fumigation. Generally, the late stage of incubation (16pipping) represented the same trend of embryonic mortality due to disinfection treatments. The accumulated embryonic mortality in the whole incubation period $(0$ - pipping) showed that the highest significant $(\mathrm{P} \leq 0.05)$ percentages of embryonic mortalities were observed for eggs disinfected with ethyl alcohol $70 \%$ and control groups, whereas the lowest ones were detected for eggs disinfected with both concentrations of propolis ( 7 and $14 \%$ ) and formaldehyde fumigation. The decrease of embryonic mortality in groups treated with both concentrations of propolis and formaldehyde fumigation could be explained on the light of ability of propolis and formaldehyde fumigation for killing the microbes on the eggshell surface before penetration through the shell pores. Also, the increase of embryonic mortality in control untreated eggshell is an indication of the increase of bacterial load on the surface of eggshell and bacterial multiplication either in the surface of the shell or inside the eggs. The results of embryonic mortality are keeping with those reported by Cook et al.(2005) who mentioned that the microbes on eggshells of newly laid eggs can multiply rapidly when exposed to appropriate ambient conditions, and penetrate the eggshell through pores, this could lead to dramatic reduction in hatching success. Also, Zeweil et al. (2013) mentioned that the formaldehyde fumigation and control groups recorded the highest percentages of 
embryonic mortality during the late stage of incubation compared to those for all egg groups. Contrary to the results of the present study, Copur et al. (2010) stated that disinfections had no increasing effect on early embryonic mortality. Regarding the egg disinfection with formaldehyde fumigation, our results are contradicted with those reported by Yildirim et al.(2003) who mentioned that significantly higher early embryonic mortality was observed in formaldehyde fumigation in comparison to oregano vulgaris and control groups.

Effects of hatching eggs disinfection on macroscopic egg fertility and hatchability percentages are shown in Table 4. No apparent significant influence of disinfectants used and formaldehyde fumigation on macroscopic fertility while the worst significant values were observed in thyme oil disinfectants. These results of macroscopic fertility did not express the real fertility but includes the early dead embryos which could not seen by the naked eye and needs microscope for detection. Hatchability percentage either for fertile or total egg set represented the best significant results for both propolis concentrations and formaldehyde fumigation groups. The worst percentages of hatchability of fertile eggs were recorded for control and ethyl alcohol $70 \%$ groups. Also, control group and thyme oil $0.5 \%$ recorded the lowest percentages of hatchability of total eggs set. Taken together the results of egg weight loss as presented in Table 2 and hatchability results in Table 4 revealed that the highest percentage of egg weight loss during incubation $(0-18$ days $)$ for control group had the worst percentages of hatchability. Moreover, the decrease of egg weight loss percentage for propolis $14 \%$ group could be a one from the reasons which contribute in increasing hatchability percentages of total set of eggs. These results are keeping with those reported by McDaniel et al. (1979) who found that eggs with the greatest weight loss had the lowest hatchability. Also, the significant decrease of total embryonic mortality as demonstrated in Table 3 for groups of both propolis concentrations and formaldehyde fumigation could be the reason for the significant increase of hatchability of total eggs for this groups. Different research works done for the disinfection of hatching eggs had different results and conclusions. Aygun et al. (2012) used propolis for egg disinfection and they found that this material had no adverse effect on the hatchability of total eggs. Therefore, we support the notion of Yildirim et al. (2003) who reported that the hatch of fertile eggs in alcohol and control groups have been slightly lower than oregano vulgaris and they found a significant difference between oregano vulgaris and formaldehyde fumigation in the hatchability of fertile eggs. On the other hand, Barbour et al. (1985) stated that formaldehyde had no adverse effect on hatchability. Yildirim and Ozcan (2001) and Copur et al. (2010) found that there were no significant differences between hatchability of oregano oil and formaldehyde fumigation groups.

Hatchability percentages had been improved for groups of propolis and fumigation but fumigation had harmful influence on human health, while propolis could be used safely as natural disinfectant. Therefore using propolis $14 \%$ could be recommended as a good alternative egg disinfectant for realizing the best results of hatching success.

Effects of egg disinfection on chick body weight at hatch and at pull out (gm) and chick body weight loss in the hatcher either absolute weight (gm) or percentage bases are shown in Table 5 . Data of this table revealed that the heaviest chick body weight at hatch $(38.60 \mathrm{gm})$ and at pull out $(37.20 \mathrm{gm})$ were recorded for chicks produced from group treated with propolis $14 \%$ compared with those produced from other egg treatments. Significant increases of chick body weight at hatch and at pull out for propolis $14 \%$ group were observed compared to other egg treated groups 
except that of ethyl alcohol $70 \%$ and formaldehyde fumigation in which the statistical difference was not observed. On the other hand, the worst significant $(\mathrm{P} \leq$ 0.05 ) chick body weight at hatch was observed for groups treated with control untreated $(33.60 \mathrm{gm})$, thyme oil $0.5 \%$ (34.60gm) and $0.7 \%$ (35.0gm) compared with those produced from other treated groups. Generally, the same worst chick body weight at pull out was recorded for groups of control untreated $(31.40 \mathrm{gm})$, thyme oil $0.5 \% \quad(32.80 \mathrm{gm})$ and $0.7 \%$ (33.16gm) compared with those produced from other treated groups. Chick body weight loss percentage in the hatcher by grams did not represent any significant difference between experimental groups but could be noticed that the highest loss percentage was recorded for control untreated group. Moreover, highest significant weight loss percentages were detected for chicks of propolis $7 \%$, thyme oil $0.5,0.7 \%$ and control untreated groups compared with the others. Besides, chicks of propolis 14\% group had the lowest chick weight loss percentage compared with all other treatment groups. As can be seen from this table that largest body weights were observed for chicks either at hatch or at pull out for propolis $14 \%$ and these results could be related with the results of decreasing egg weight loss during incubation as presented in Table 2. These results are confirmed with those reported by Peebles et al. (1987) who showed that chick weight was reduced by increasing incubation egg weight loss from zero to 18 days. Also, Davis et al. (1988) reported that low or excess water are incorporated into new tissues so affecting chick weight. Moreover, the increase of chick weight loss percentages might related with the smaller size of chick body weight as lowest weights of chick body in this table had the highest chick weight loss percentage. This conclusion is in accordance with those reported by Lynn (2006) who mentioned that small chicks have higher surface area to weight ratio and therefore more easily dehydrated than longer chicks.

Effects of hatching disinfection on minimum, maximum and range of hatch time for chicks are shown in Table 6 . The shortest hatch time $(468.0 \mathrm{hrs})$ was recorded for chicks produced from eggs treated with ethyl alcohol $70 \%$ and this minimum of hatch time was advanced by 3 hrs compared with those for propolis $14 \%$. Moreover, maximum record of hatch time $(\mathrm{P} \leq 0.05)$ was recorded for eggs treated with thyme oil 0.5 and $0.7 \%$ and control untreated $(503.0 \mathrm{hrs})$ compared to least maximum record of hatch time for ethyl alcohol 70\% ( $498.0 \mathrm{hrs}$ ). Moreover, this table revealed that the shortest range between maximum and minimum hatch time was recorded for propolis 14\% (29.0 hrs), while the longest range of hatch time was observed for control untreated group (34.0 hrs). Range of hatch time is a good indicator for chick distribution in the hatcher and it is preferable to reduce this range and shorten the staying of chicks in the hatcher to avoid chick dehydration. The results of the reduction of range time for both concentrations of propolis as demonstrated in the results of Table 6 compared with control are in accordance with those previously mentioned by Mona (2011) who reported that the shortest range of hatch time was recorded for chicks produced from eggs treated with natural disinfectants.

Effects of hatching egg disinfection on embryonic weight (gm) at different ages during incubation are shown in Table 7. From this table it could be noticed that average of embryonic weight for eggs treated with propolis $14 \%(0.86 \mathrm{gm})$ at day 5 was the heaviest $(\mathrm{P} \leq 0.05)$ followed by those for ethyl alcohol $70 \%$ (0.71gm) , propolis $7 \%(0.60 \mathrm{gm})$, thyme oil $0.7 \%$ $(0.60 \mathrm{gm})$ and finally control untreated $(0.48 \mathrm{gm})$. On day eighteen of incubation, embryonic weight for eggs treated by propolis $14 \%(26.66 \mathrm{gm})$ was the heaviest and the lowest one $(23.0 \mathrm{gm})$ was recorded 
for control untreated group. The increase of embryonic weight for propolis disinfection is a good criterion for embryonic development and it is supposed that this natural disinfectant did not adversely affect the cuticle and eggshell properties. These results are in harmony with those reported by Brake (1987) who mentioned that the cuticle may be affected by application of sanitizers so as alter embryonic development.Also, the decrease of water loss or water vapour in eggs of propolis group as previously mentioned in Table 2 may influence the development of the embryos. Ar and Rahn (1980) mentioned that water loss across the eggshell during incubation and more water was produced by oxidation of yolk. The rate of water loss is the product water vapour conductance and water vapour pressure difference across the eggshell (Paganelli, 1980). Increased or decreased water loss decreases hatching success (Lundy, 1969) and may influence growth and development of the embryo (Simkiss, 1980; Tullett and Deeming, 1987).

Application of disinfectants and formaldehyde fumigation had significant influence on TBC, TCC and TSC compared to control untreated either at day of laying or after four days of storage (Table 8).The best significant results of TBC at day of laying was observed for formaldehyde fumigation and propolis $14 \%$ as they decreased from $45.30 \times 10^{3} \mathrm{cfu} / \mathrm{egg}$ for control untreated to 16.62 and $17.11 \times 10^{3}$ cfu /egg for fumigation and propolis $14 \%$ groups, respectively. Apparently, data of this table revealed that as the concentrations of propolis increased from $7 \%$ to $14 \%$, TBC decreased from 21.79 to $17.11 \times 10^{3} \mathrm{cfu} / \mathrm{egg}$. The same trend of decreasing TBC for propolis was observed for fumigation of eggs after four days of storage. Total bacterial count on eggshell surface was significantly increased in control untreated group from $45.30 \times 10^{3}$ $\mathrm{cfu} / \mathrm{egg}$ at day of laying to $73.14 \times 10^{3} \mathrm{cfu}$ legg after four days of storage. The best results of residual effect was detected in propolis $14 \%$ as they significantly decreased from $17.11 \times 10^{3} \mathrm{cfu} / \mathrm{egg}$ at day of laying to $5.3 \times 10^{3} \mathrm{cfu} / \mathrm{egg}$ after four days of storage, while the worst residual effect of disinfection was observed with thyme oil $0.5 \%$ as they significantly decreased from 38.77 to $32.01 \times 10^{3}$ cfu/egg after four days of storage. Moreover, both concentrations of propolis (7\% and 14\%) besides fumigation significantly $(\mathrm{P} \leq 0.05)$ realized the best reduction of TCC on eggshell surface compared with those for control untreated at day of laying. The same significant reduction of TCC was observed in total Staphylococcus for propolis $14 \%$ and formaldehyde fumigation groups. Total coliform count was significantly increased from $7.27 \times 10^{3} \mathrm{cfu} / \mathrm{egg}$ at day of laying to $19.22 \times 10^{3} \mathrm{cfu} / \mathrm{egg}$ after four days of storage for control untreated group , besides TSC was significant increased from 5.87 to $14.67 \times 10^{3} \mathrm{cfu} / \mathrm{egg}$ for the same control groups.

Data presented in Table 8 revealed that the growth of bacteria will increase on the shell surface after storage for eggs without any treatment of disinfection as in control group. Also, using propolis $14 \%$ and fumigation could be recommended for decreasing each of TBC, TCC and TSC on eggshell surface. Most of the disinfectants used had residual effect on eggshell surface for longer time of storage as most of the counts decreased after four days of storage, while fumigation did not possess the same character of residually. Reduction the bacterial count through application of disinfectants on eggshell surface such as propolis could be assumed a good method for diminishing the number of contaminated hatched chicks and in turn decreasing the cross contamination during incubation.

Different research works had been done on the effect of disinfection on hatching eggs. Supporting to results herein regarding the effect of propolis as 
antimicrobial materials, Alencar et al. (2007) and Rahman et al. (2010) stated that propolis has antimicrobial against Staphylococcus species. Also, spraying the eggs with propolis in the current study had lower levels of total aerobic mesophilic bacteria, and Coliform compared to control over the storage period and these conclusions are in accordance with those reported by Aygun and Sert (2013). The propolis mode of action as antimicrobial was expressed on hatchability and hatched chick body weight improvements.

The application of ethyl alcohol $70 \%$ treatment on hatching eggshell significantly $(\mathrm{P}<0.05)$ decreased $\mathrm{TBC}$ by storage time from 24.16 to $8.30 \times 10^{3} \mathrm{cfu} / \mathrm{egg}$ at $1^{\text {st }}$ and $4^{\text {th }}$ days, respectively. This count reduction is in harmony with those reported by Nowaczewski et al. (2013) who mentioned that eggshells were characterized by significant lowering of $\mathrm{TBC}$ and total fungal. Based on their survey, ethyl alcohol $75 \%$ proved to be an effective disinfectant of Japanese quail eggshells before incubation.
Supporting to our results regarding the reduction of $\mathrm{TBC}$ due to fumigation, Debes and Basyony (2011) reported that formaldehyde fumigation significantly decreased TBC from $52 \times 10^{3} \mathrm{cfu} / \mathrm{egg}$ in untreated group to $24 \times 10^{3} \mathrm{cfu} / \mathrm{egg}$. Whereas, Sacco et al. (1989) observed that turkey eggs treated with formaldehyde fumigation eliminated the majority of eggshell microorganisms population. Also our study revealed that the prolongation of formaldehyde fumigation treatment time had no significant influence on TBC of hatching eggshell as decreased from 16.62 to $11.19 \times 10^{3} \mathrm{cfu} / \mathrm{egg}$ at $1^{\text {st }}$ and $4^{\text {th }}$ day, respectively.

It could be concluded that using propolis $14 \%$ as natural disinfectant for hatching eggs may provide an alternative treatment option for controlling microbial load during the storage and consequently in incubation periods. Propolis realized the best results of hatchability, chick body weight and confined hatched chicks in shortest time to overcome the scattered hatch. Based on the current results, propolis may be an effective, safe and nontoxic natural as hatching egg disinfectant.

Table (2): Effect of hatching eggs disinfection on egg weight loss percentage of fertile eggs during different incubation intervals

\begin{tabular}{|c|c|c|c|c|}
\hline \multirow{2}{*}{ Treatment } & \multicolumn{4}{|c|}{ Egg weight loss percentage } \\
\hline & 0 - 5 day & 6 - 10 day & 11 - 18 day & 0 - 18 day \\
\hline Propolis $14 \%$ & $2.87 \pm 0.21^{b}$ & $2.59 \pm 0.16$ & $4.32 \pm 0.47$ & $9.79 \pm 0.62^{b}$ \\
\hline Propolis $7 \%$ & $3.00 \pm 0.22^{\mathrm{ab}}$ & $2.68 \pm 0.15$ & $4.85 \pm 0.21$ & $10.54 \pm 0.37^{\mathrm{ab}}$ \\
\hline Thyme oil $0.5 \%$ & $2.98 \pm 0.22^{\mathrm{ab}}$ & $2.67 \pm 0.16$ & $4.67 \pm 0.49$ & $10.32 \pm 0.53^{b}$ \\
\hline Thyme oil $0.7 \%$ & $2.89 \pm 0.26^{\mathrm{b}}$ & $2.65 \pm 0.16$ & $4.41 \pm 0.42$ & $9.95 \pm 0.50^{b}$ \\
\hline Ethyl alcohol 70\% & $3.45 \pm 0.29^{\mathrm{ab}}$ & $2.75 \pm 0.29$ & $4.78 \pm 0.43$ & $10.99 \pm 0.56^{\mathrm{ab}}$ \\
\hline Formaldehyde fumigation & $3.05 \pm 0.16^{\mathrm{ab}}$ & $2.73 \pm 0.22$ & $4.90 \pm 0.32$ & $10.68 \pm 0.36^{\mathrm{ab}}$ \\
\hline Control untreated & $3.68 \pm 0.23^{\mathrm{a}}$ & $2.89 \pm 0.18$ & $5.32 \pm 0.29$ & $11.90 \pm 0.45^{\mathrm{a}}$ \\
\hline
\end{tabular}

$\mathrm{a}$ and $\mathrm{b}$ means within each column for each item with different superscripts are significantly different $(\mathrm{P}<0.05)$ 
Table (3): Effect of hatching eggs disinfection on embryonic mortality during different stages of incubation

\begin{tabular}{|c|c|c|c|c|}
\hline \multirow[b]{2}{*}{ Treatment } & \multicolumn{4}{|c|}{ Embryonic mortality percentage } \\
\hline & $\begin{array}{r}\text { Early stage } \\
\text { (O -6 days) }\end{array}$ & $\begin{array}{c}\text { Mid stage } \\
\text { (7 -15 days) }\end{array}$ & $\begin{array}{l}\text { Late stage } \\
16 \text {-pipped }\end{array}$ & $\begin{array}{c}\text { Total } \\
\text { embryonic } \\
\text { mortality } \\
\text { (O-pipping) }\end{array}$ \\
\hline Propolis $14 \%$ & $1.46 \pm 0.05^{\mathrm{c}}$ & $1.03 \pm 0.002^{\mathrm{d}}$ & $0.76 \pm 0.004^{\mathrm{c}}$ & $3.26 \pm 0.04^{\mathrm{d}}$ \\
\hline Propolis $7 \%$ & $2.0 \pm 0.41^{\mathrm{bc}}$ & $1.0 \pm 0.0^{\mathrm{d}}$ & $1.0 \pm 0.0^{\mathrm{c}}$ & $4.0 \pm 0.41^{\mathrm{d}}$ \\
\hline Thyme oil $0.5 \%$ & $3.0 \pm 0.41^{\mathrm{b}}$ & $3.10 \pm 0.41^{\mathrm{b}}$ & $2.80 \pm 0.41^{\mathrm{b}}$ & $8.90 \pm 0.41^{\mathrm{b}}$ \\
\hline Thyme oil $0.7 \%$ & $2.20 \pm 0.41^{\mathrm{bc}}$ & $2.0 \pm 0.41^{\mathrm{c}}$ & $2.60 \pm 0.41^{\mathrm{b}}$ & $6.80 \pm 1.22^{\mathrm{c}}$ \\
\hline Ethyl alcohol $70 \%$ & $5.13 \pm 0.38^{\mathrm{a}}$ & $3.80 \pm 0.41^{\mathrm{ab}}$ & $3.85 \pm 0.41^{\mathrm{a}}$ & $12.78 \pm 0.38^{\mathrm{a}}$ \\
\hline Formaldehyde fumigation & $2.40 \pm 0.40^{\mathrm{bc}}$ & $1.10 \pm 0.0^{\mathrm{cd}}$ & $1.0 \pm 0.0^{\mathrm{c}}$ & $4.50 \pm 0.40^{\mathrm{d}}$ \\
\hline Control untreated & $6.20 \pm 0.41^{\mathrm{a}}$ & $4.50 \pm 0.41^{\mathrm{a}}$ & $3.23 \pm 0.42^{\mathrm{ab}}$ & $13.93 \pm 0.42^{\mathrm{a}}$ \\
\hline
\end{tabular}

a,b,c and d means within each column for each item with different superscripts are significantly different $(\mathrm{P}<0.05)$

Table (4): Effect of hatching eggs disinfection on macroscopic egg fertility and hatchability percentages

\begin{tabular}{|l|l|l|l|}
\hline Treatment & $\begin{array}{c}\text { Macroscopic egg } \\
\text { fertility (\%) }\end{array}$ & $\begin{array}{l}\text { Hatchability of } \\
\text { fertile eggs (\%) }\end{array}$ & $\begin{array}{c}\text { Hatchability of } \\
\text { total eggs (\%) }\end{array}$ \\
\hline Propolis 14\% & $95.60 \pm 0.58^{\mathrm{a}}$ & $95.76 \pm 0.60^{\mathrm{a}}$ & $90.88 \pm 0.90^{\mathrm{a}}$ \\
Propolis 7\% & $93.87 \pm 0.54^{\mathrm{ab}}$ & $96.58 \pm 0.51^{\mathrm{a}}$ & $90.73 \pm 0.54^{\mathrm{a}}$ \\
Thyme oil 0.5\% & $91.45 \pm 0.60^{\mathrm{c}}$ & $90.32 \pm 0.60^{\mathrm{c}}$ & $82.52 \pm 0.52^{\mathrm{cd}}$ \\
Thyme oil 0.7\% & $92.52 \pm 0.54^{\mathrm{bc}}$ & $92.57 \pm 0.60^{\mathrm{b}}$ & $85.58 \pm 0.54^{\mathrm{b}}$ \\
Ethyl alcohol 70\% & $95.20 \pm 0.58^{\mathrm{a}}$ & $87.03 \pm 0.60^{\mathrm{d}}$ & $83.23 \pm 0.60^{\mathrm{c}}$ \\
Formaldehyde fumigation & $94.58 \pm 0.54^{\mathrm{a}}$ & $95.32 \pm 0.54^{\mathrm{a}}$ & $90.73 \pm 0.54^{\mathrm{a}}$ \\
Control untreated & $94.58 \pm 0.60^{\mathrm{a}}$ & $85.62 \pm 0.60^{\mathrm{d}}$ & $80.75 \pm 0.54^{\mathrm{d}}$ \\
\hline
\end{tabular}

$\mathrm{a}, \mathrm{b}, \mathrm{c}$ and $\mathrm{d}$ means within each column for each item with different superscripts are significantly different $(\mathrm{P}<0.05)$ 
Table (5): Effect of hatching eggs disinfection on chick body weight and chick weight loss in the hatcher

\begin{tabular}{|l|l|l|l|l|}
\hline \multirow{2}{*}{\multicolumn{1}{|c|}{ Treatment }} & \multicolumn{2}{|c|}{ Chick body weight (gm) } & \multicolumn{2}{c|}{ Chick weight loss } \\
\cline { 2 - 5 } & \multicolumn{1}{|c|}{ At hatch } & At pull out & $(\mathbf{g m})$ & $(\%)$ \\
\hline Propolis 14\% & $38.60 \pm 0.58^{\mathrm{a}}$ & $37.20 \pm 0.57^{\mathrm{a}}$ & $1.40 \pm 0.16$ & $3.62 \pm 0.41^{\mathrm{b}}$ \\
Propolis 7\% & $35.83 \pm 0.92^{\mathrm{bc}}$ & $34.16 \pm 0.87^{\mathrm{bc}}$ & $1.66 \pm 0.22$ & $4.61 \pm 0.58^{\mathrm{ab}}$ \\
Thyme oil 0.5\% & $34.60 \pm 0.88^{\mathrm{c}}$ & $32.80 \pm 0.67^{\mathrm{cd}}$ & $1.80 \pm 0.38$ & $5.07 \pm 0.96^{\mathrm{ab}}$ \\
Thyme oil 0.7\% & $35.0 \pm 0.55^{\mathrm{c}}$ & $33.16 \pm 0.61^{\mathrm{cd}}$ & $1.83 \pm 0.31$ & $5.24 \pm 0.87^{\mathrm{ab}}$ \\
Ethyl alcohol 70\% & $37.40 \pm 0.58^{\mathrm{ab}}$ & $36.0 \pm 0.63^{\mathrm{ab}}$ & $1.40 \pm 0.16$ & $3.76 \pm 0.45^{\mathrm{b}}$ \\
Formaldehyde fumigation & $37.50 \pm 1.09^{\mathrm{ab}}$ & $36.0 \pm 1.01^{\mathrm{ab}}$ & $1.50 \pm 0.15$ & $3.96 \pm 0.36^{\mathrm{b}}$ \\
Control untreated & $33.60 \pm 0.45^{\mathrm{c}}$ & $31.40 \pm 0.33^{\mathrm{d}}$ & $2.20 \pm 0.24$ & $6.49 \pm 0.69^{\mathrm{a}}$ \\
\hline
\end{tabular}

$\mathrm{a}, \mathrm{b}, \mathrm{c}$ and $\mathrm{d}$ means within each column for each item with different superscripts are significantly different $(\mathrm{P}<0.05)$

Table (6): Effect of hatching eggs disinfection on the minimum, maximum and range of hatch time for chicks

\begin{tabular}{|l|l|l|l|}
\hline \multirow{2}{*}{\multicolumn{1}{|c|}{ Treatment }} & \multicolumn{3}{|c|}{ Hatch time (hrs) } \\
\cline { 2 - 4 } & \multicolumn{1}{|c|}{$\begin{array}{c}\text { Minimum } \\
\text { record }\end{array}$} & $\begin{array}{c}\text { Maximum } \\
\text { record }\end{array}$ & \multicolumn{1}{c|}{ Range } \\
\hline Propolis 14\% & $471.0 \pm 1.73$ & $500.0 \pm 1.15^{\mathrm{b}}$ & $29.0 \pm 2.88$ \\
Propolis 7\% & $469.0 \pm 0.57$ & $500.0 \pm 0.0^{\mathrm{b}}$ & $31.0 \pm 0.57$ \\
Thyme oil 0.5\% & $470.0 \pm 2.0$ & $503.0 \pm 2.51^{\mathrm{a}}$ & $33.0 \pm 2.51$ \\
Thyme oil 0.7\% & $470.0 \pm 0.57$ & $503.0 \pm 0.0^{\mathrm{a}}$ & $33.0 \pm 0.57$ \\
Ethyl alcohol 70\% & $468.0 \pm 0.57$ & $498.0 \pm 0.57^{\mathrm{c}}$ & $30.0 \pm 1.15$ \\
Formaldehyde fumigation & $470.0 \pm 0.57$ & $500.0 \pm 0.0^{\mathrm{b}}$ & $30.0 \pm 0.57$ \\
Control untreated & $469.0 \pm 0.57$ & $503.0 \pm 0.0^{\mathrm{a}}$ & $34.0 \pm 0.57$ \\
\hline
\end{tabular}

$\mathrm{a}, \mathrm{b}$ and $\mathrm{c}$ means within each column for each item with different superscripts are significantly different $(\mathrm{P}<0.05)$

Table (7): Effect of hatching eggs disinfection on embryonic weight at different ages of incubation

\begin{tabular}{|l|l|l|l|}
\hline \multirow{2}{*}{\multicolumn{1}{|c|}{ Treatment }} & \multicolumn{3}{|c|}{ Embryonic weight $(\mathbf{g m})$} \\
\cline { 2 - 4 } & \multicolumn{1}{|c|}{$\mathbf{5}^{\text {th }}$ day } & \multicolumn{1}{c|}{$\mathbf{1 0}^{\text {th }}$ day } & \multicolumn{1}{c|}{ day } \\
\hline Propolis 14\% & $0.86 \pm 0.03^{\mathrm{a}}$ & $4.33 \pm 0.3$ & $26.66 \pm 0.66^{\mathrm{a}}$ \\
Propolis 7\% & $0.60 \pm 0.05^{\mathrm{bcd}}$ & $4.83 \pm 0.44$ & $25.0 \pm 0.57^{\mathrm{ab}}$ \\
Thyme oil 0.5\% & $0.53 \pm 0.03^{\mathrm{cde}}$ & $4.23 \pm 0.14$ & $24.50 \pm 0.28^{\mathrm{b}}$ \\
Thyme oil 0.7\% & $0.60 \pm 0.05^{\mathrm{bcd}}$ & $4.10 \pm 0.05$ & $25.0 \pm 0.57^{\mathrm{ab}}$ \\
Ethyl alcohol 70\% & $0.71 \pm 0.01^{\mathrm{b}}$ & $4.60 \pm 0.20$ & $25.66 \pm 0.88^{\mathrm{ab}}$ \\
Formaldehyde fumigation & $0.63 \pm 0.06^{\mathrm{bc}}$ & $4.50 \pm 0.28$ & $25.33 \pm 0.33^{\mathrm{ab}}$ \\
Control untreated & $0.48 \pm 0.01^{\mathrm{de}}$ & $4.33 \pm 0.33$ & $23.0 \pm 0.57^{\mathrm{c}}$ \\
\hline
\end{tabular}

$a, b, \ldots$ and e means within each column for each item with different superscripts are significantly different $(\mathrm{P}<0.05)$ 
Table(8): Effect of hatching egg disinfection on bacteriological activity of eggshell surface eggs (X $10^{3} \mathrm{cfu} / \mathrm{egg}$ ) at laying day and after four days of storage

\begin{tabular}{|l|l|l|l|l|l|l|}
\hline \multirow{2}{*}{\multicolumn{1}{|c|}{ Treatment }} & \multicolumn{2}{c|}{ Total bacterial count } & \multicolumn{2}{c|}{ Total Coliform count } & \multicolumn{2}{c|}{ Total Staphylococcus count } \\
\cline { 2 - 7 } & \multicolumn{1}{|c|}{ At laying day } & $\begin{array}{c}4^{\text {th }} \text { day of } \\
\text { storage }\end{array}$ & $\begin{array}{c}\text { laying day } \\
\text { At }\end{array}$ & $\begin{array}{c}4^{\text {th }} \text { day of } \\
\text { storage }\end{array}$ & $\begin{array}{c}\text { laying day } \\
\text { At }\end{array}$ & $\begin{array}{c}4^{\text {th }} \text { day of } \\
\text { storage }\end{array}$ \\
\hline Propolis 14\% & $17.11 \pm 1.09^{\mathrm{eA}}$ & $5.30 \pm 0.37^{\mathrm{fB}}$ & $2.04 \pm 0.13^{\mathrm{Ea}}$ & $1.21 \pm 0.08^{\mathrm{eB}}$ & $1.87 \pm 0.09^{\mathrm{eA}}$ & $1.04 \pm 0.04^{\mathrm{eB}}$ \\
Propolis 7\% & $21.79 \pm 1.21^{\mathrm{dA}}$ & $14.48 \pm 0.79^{\mathrm{cdB}}$ & $2.54 \pm 0.18^{\mathrm{e}}$ & $2.36 \pm 0.13^{\mathrm{cd}}$ & $2.40 \pm 0.13^{\mathrm{cdA}}$ & $2.09 \pm 0.13^{\mathrm{dB}}$ \\
Thyme oil 0.5\% & $38.77 \pm 2.09^{\mathrm{bA}}$ & $32.01 \pm 2.16^{\mathrm{bB}}$ & $5.05 \pm 0.26^{\mathrm{bA}}$ & $4.14 \pm 0.20^{\mathrm{bB}}$ & $3.69 \pm 0.19^{\mathrm{bA}}$ & $3.11 \pm 0.13^{\mathrm{bB}}$ \\
Thyme oil 0.7\% & $29.40 \pm 1.20^{\mathrm{cA}}$ & $15.10 \pm 0.71^{\mathrm{cB}}$ & $3.93 \pm 0.12^{\mathrm{cA}}$ & $2.81 \pm 0.15^{\mathrm{cB}}$ & $2.74 \pm 0.09^{\mathrm{c}}$ & $2.52 \pm 0.13^{\mathrm{c}}$ \\
Ethyl alcohol 70\% & $24.16 \pm 1.25^{\mathrm{dA}}$ & $8.30 \pm 0.39^{\mathrm{efB}}$ & $3.40 \pm 0.12^{\mathrm{dA}}$ & $1.95 \pm 0.13^{\mathrm{dB}}$ & $2.35 \pm 0.15^{\mathrm{cdA}}$ & $1.86 \pm 0.12^{\mathrm{dB}}$ \\
Formaldehyde fumigation & $16.62 \pm 1.01^{\mathrm{eA}}$ & $11.19 \pm 0.53^{\mathrm{deB}}$ & $2.17 \pm 0.13^{\mathrm{e}}$ & $1.99 \pm 0.14^{\mathrm{d}}$ & $2.17 \pm 0.12^{\mathrm{de}}$ & $2.04 \pm 0.12^{\mathrm{d}}$ \\
Control untreated & $45.30 \pm 1.81^{\mathrm{aB}}$ & $73.14 \pm 2.15^{\mathrm{aA}}$ & $7.27 \pm 0.20^{\mathrm{aB}}$ & $19.22 \pm 0.23^{\mathrm{aA}}$ & $5.87 \pm 0.16^{\mathrm{aB}}$ & $14.67 \pm 0.16^{\mathrm{aA}}$ \\
\hline
\end{tabular}

$\mathrm{a}, \mathrm{b} . . . .$. and $\mathrm{f}$ means within each column for each item with different superscripts are significantly different $(\mathrm{P}<0.05)$

$\mathrm{A}$ and $\mathrm{B}$ means within each row for each item with different superscripts are significantly different $(\mathrm{P} \leq 0.05)$ 


\section{REFERENCES}

Abd El-Hady FK.; and Hegazi, AG., 1994. Gas chromatography - mass spectrometry (GC/MS) study of the Egyptian propolis 1- aliphatic, phenolic acids and their esters. Egypt J.Appl.Sci.9:749-760.

Aygun,A.; Sert,D.; and Couper,G.,2012. Effects of propolis on eggshell microbial activity, hatchability, and chick performance in Japanese quail (Coturnix coturnix japonica) eggs. Poult.Sci.91: 1018 -1025.

Aygun, A.; and Sert, D., 2013. Effects of prestorage application of propolis and storage time on eggshell microbial activity, hatchability, and chick performance in Japanese quail (Coturnix coturnix japonica) eggs. Poult. Sci. 92: 3330-3337.

Alencar,S.M.; Oldoni,T.L.; Castro,M.L.; Cabral,I.S.; $\quad$ CostaNeto,C.M.; Cury,J.A.; Rosalen,P.L.; and Ikegaki,m.,2007. Chemical composition and biological activity of a new type of Brazilian propolis: Red propolis, J. Ethnopharmacol. 113:278 - 283.

Ar,A.; and Rahn,H.,1980. Water in the avian egg overall budget of incubation.Amer. Zool. 20:373 384.

BAM., 2005. USFDA for Detection, Enumeration and Identification of Individual Organisms. Bacteriological Analytical Manual Website: fda BAM. html. Accessed on 17-04-2010.

Bankova, V.S.; Castro,S.L.; and Marcucci,M.C.,2000. Propolis: Recent advances in chemistry and plant origin. Apidologie. 31:3 - 15 .

Barbour, E.K.; Nabbut, N.H.; Hinners,S.W.; and ALNakhli,H.M., 1985. Reduction of bacterial infections in newly hatched chicks by the use of antimicrobial dips: Preliminary approaches.Vet.Quarterly.7:39 -43.

Brake, J.T., 1987. Influence of presence of perches during rearing on incidence of floor laying in broiler breeders. Poult.Sci. 66:1587 -1589.

Brake,J.; and Sheldon,B.W., 1990. Effect of a quaternary ammonium sanitizer for hatching eggs on their contamination, permeability, water loss and hatchability.Poult.Sci. 69:517 -525.

Bramwell, R. K., 2000. Importancia de las prácticas de manejo de lãs casetas de reprodutoras. Indústria Avícola. 47: 8-18.

Burton,F.G.; and Tullett,S.G.,1983. A comparison of the effect of eggshell porosity on the respiration and growth of domestic fowl, duck and turkey embryos.Com.,Bio. and Phy.75:167-174.

Cadirci, S., 2009. Disinfection of hatching eggs by formaldehyde fumigation a review.Arch.Geflügelk. 73:116-123.

Cook,M.I.;

Beissinger,S.R.;

Toranzos,G.A.; and

Arendt,W.J.,2005. Microbial infection affects egg viability and incubation behavior in a tropical passerine.Behav.Ecol.16:30 - 36 .

Copur,G.; Camci,O.; Sahinler,N.; and Gul,A.,2008. The effect of propolis eggshell coatings on interior egg quality.Arch.Geflügelkd.72:35 - 40.

Copur,G.; Arslan,M.; Duru,M.; Baylan,M.; Canogullari,S.; and Aksan,E.,2010. Use of oregano (Origanum onites L.) essential oil as hatching egg disinfectant. African, J.of Bio. 8:2531 -2538.

Davis,T.A.; and Ackerman,R.,1987. Effects of increased water loss on growth and water content of the chick embryo.J.Exp.Zool.Suppl. 1:357-364. 
Davis, T.A.; Shen,S.S.; and Acherman,R.A., 1988. Embryonic osmoregulation: Consequences of high and low water loss during incubation of the chicken egg. J.Exp.Zool. 245:144 -156.

Debes, A.; and Basyony, M., 2011. The use of oregano (Origanum vulgare L) and ginger (Zingiber officinale) oils as alternative hatching disinfectant versus formaldehyde fumigation in Leghorn and Matrouh eggs. Egypt. Poult. Sci. Vol. 31: 755-765.

Duncan's, D. B., 1955. Multiple range and multiple $\mathrm{F}$ test. Biometrics. 11: 142.

Fabio, A.; Corona, A.;Forte,E.; and Quaglio,P., 2003. Inhibitory activity of spices and essential oils on psychrotrophic bacterial. New Microbial.26:115-120.

Geng,Z.Y.; and Wang,X.L., 1990. Relationship of hatchability and the percentage of egg weight loss and shell pore concentration during incubation.Chin.J.Anim.Sci.26:1214.

Gentry,R.F.; and Quarles,C.L., 1972. The measurement of bacterial contamination on eggshells. Poult.Sci. 51:930-933.

Hayretda, S.; and Kolankaya, D., 2008. Investigation of the effects of preincubation formaldehyde fumigation on the tracheal epithelium of chicken embryos and chicks Turk. Journal of Veterinary Research and Animal Science. 32: 263-267.

Hoyt, D.F., 1980. Adaptation of avian eggs to incubation period: Variability a round allometric regression is corrected with time. Amer. Zool. 20:417-425.

Jones, D. R.; Anderson K. E.; Curtis, P. A.; and Jones, F. T., 2002. Microbial contamination in inoculated shell eggs: I. Effects of layer strain and hen age. Poult. Sci. 81:715-720.

Krell, R., 1996. Value-added products from bee keeping.FAO Agricultural Services Bulletin No: 124. Food and Agriculture Organization of the United Nations, Room. Italy.

Kuo, F.L.; Carey,J.B.; Ricke,S.C.; and Ha,S.D., 1996. Peroxidase catalyzed chemical dip, egg shell surface contamination, and hatching. J.Appl.Poult.Res. 5:6-13.

Kuo,F.L.; Carey,J.B.; and Ricke,S.C., 1997. UV irradiation of shell eggs: Effect on populations of aerobes,molds, and inoculated Salmonella Typhimurium,. Food Prot. 60:639-643.

Lundy, H., 1969. A review of the effects of temperature,turning and gaseous environment in the incubator on the hatchability of the hen's egg. In: The fertility and hatchability of the hen's egg (ed.Carter and Freeman), Oliver and Boyd,Edinburgh.

Lynn, F., 2006. Egg size eggshell conductance and incubation temperature influence on maturity of commercial turkey poults. M. Sc. Thesis, fac.of North Carolina State University.

McDaniel, G.R.; Roland, D.A.; Sr.; and Coleman, M.A., 1979. The effect of egg shell quality on hatchability and embryonic mortality. Poult. Sci.58:10 -13.

Mona, R.M., 2011. Effect of egg disinfection on embryonic development, hatchability characteristics and post-hatch productive performance in local chickens.Ph.D.Thesis,Fac.of Agric (Saba-Bacha) Anim.and Fish Production Department, Alex. Univ., Egypt.

Nevas, M.; Korhonen, A. R.; Lindstrom, M.; Turkki, P.; and Korkeala, H., 2004. Antibacterial efficiency of finnish spice essential oils against 
pathogenic and spoilage bacteria. J. Food. Prot. 67: 199-202.

Nowaczewski, S.; Szablewski, T.; Cegielska-Radziejewska, R.; and Kontecka, H., 2013. Microbiological response of Japanese quail eggs to disinfection and location in the setter during incubation. Folia Biologica (Kraków), 61: 119.

Özçelik, S., 1992. Food microbiology laboratory manual. F. Univ. Publications of Faculty of Arts and Sciences, Publication. 1:s.135.

Paganelli, C.V., 1980. The physics of gas exchange across the avian eggshell.Am.Zool. 20:329 -338.

Paganelli,C.V.; Ackerman,R.A.; and Rahn,H., 1978. The avian egg: In vivo conductances to oxygen, carbon dioxide, and water vapor in late development. Pages 212-218 in: Respiratory Function in Birds, Adult and Embryonic (ed.J.piiper), Springer-Verlag,.Brlin.

Peebles,E.D.; and Brake,J.T., 1986. The role of the cuticle in water vapor conductance by the eggshell of broiler breeders. Poult. Sci. 65:1034-1039.

Peebles,E.D.; Brake,J.T.; and Gildersleeve,R.P., 1987. Effects of eggshell cuticle removal and incubation humidity on embryonic development and hatchability of broilers. Poult. Sci.66:834 -840.

Powers, J.J., 1964. Action of anthocyanias and related compounds on bacterial cells. Pages $59-75$ in Proc.Fourth Int. Sym. Food Microbiology, N.Molin,ed, Goteborg,Sweden.

Rahman, M.M.; Richardson,A.; and Sofian-Azirun,M., 2010. Antibacterial activity of propolis and honey against Staphylococcus aureus and Escherichia coli. Afr. J. Microbial. Res. 4:1872-1878.
Rahn, H.;Ar,A.; and Paganelli,C.V., 1979. How bird eggs breathe.Sci.Amer. 240:46-55.

Reinhart,B.S.; and Hurnik,G.I., 1984. Trails affecting the hatching performance of commercial chicken broiler eggs. Poult. Sci. 63:240-245.

Sacco,R.E.; Renner,P.A.; Nestor,K.E.; Saif,Y.M.; and Dearth,R.N., 1989. Effect of hatching egg sanitizers on embryonic survival and hatchability of turkey eggs from different lines on eggshell bacterial populations. Poult.Sci.68:1179 - 1184 .

Sáez, F.; and Stahl-Biskup, E., 2002. Essential oil polymorphism in the genus Thymus, In: Thyme: The Genus Thymus (Eds. E. StahlBiskup and F. Sáez), 124-143. Taylor and Francis, London and New York.

SAS, Institute., 1998. SAS Users Guide: Statistics. SAS Institute Inc. Cary,NC,USA.

Sesti,L.I., 2005. Biosseguridade em granjas de reprodutoras In: Macari,M.;Mendes,A.A.(Ed.). Manejo de matrizes de corte, Santos: Facta. p.244-317.

Simkiss,K., 1980. Eggshell porosity and the water metabolism of the chick embryo.J.Zool. 192:1 - 8.

Soliman,F.N.K., 2000. Effect of short preincubation storage periods on egg weight loss, embryonic development, chicks weight fertility and hatchability in two local chicken strains. Egypt. Poult. Sci. 20:157 -171.

Sparks,N.H.C.; and Burgess,A.D., 1993. Effect of spray sanitizing egg cuticle efficacy and hatchability. Br.Poult. Sci. 34:655-662.

Stahl-Biskup,E.; and Saez,F., 2002. Thume, The genus Thymus. Tex book. Puplished in USA. and Canada by Taylor and Francis,Inc. 
Tullett, S.G., 1990. Science and the art of incubation. Poult. Sci.69:1 -15.

Tullett,S.G.; and Deeming,D.C., 1987. Failure to turn eggs during incubation: effects on embryo weight,development of the chorioallantois and absorption of albumen. Br.Poult. Sci. 28:239-243.

Wyatt,C.L.; Weaver,Jr.W.D.; and Beane,W.L., 1985. Influence of egg size, eggshell quality, and posthatch holding time on broiler performance. Poult. Sci. 64:20492055.

Yildirim,I.; Ozcan, M.; and Yetisir, R.,2003. The use of oregano
(Origanum vulgare L.) essential oil as alternative hatching egg disinfectant versus formaldehyde fumigation in quails (Coturnix coturnix japonica) eggs. Food Control. 15:169-172.

Yildirim,I.; and Ozcan,N., 2001. Use of oregano and cumin essential oils as disinfectants on hatching Quail eggs.J.Anim.Res.Inst.11:61 -63.

Zeweil,H.S.; Rizk,R.E.; Bekhet,G.A.H.; and Mona,R.M.Ahmed,. 2013. Effects of egg disinfection on hatching performance for Bandarah chicken strain. Egyp. Poult. Sci. 33:289 -307. 


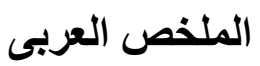

\title{
دور رش بيض التفريخ بالمطهرات الطبيعية على صفات الفقس والعد البكتيرى على قثرة البيضة
}

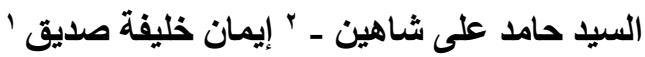

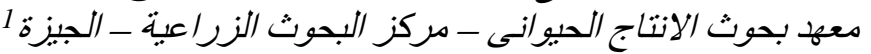

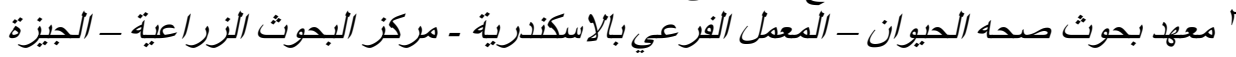

أجريت هذة التجربة لدراسة دور رش بيض التفريخ بالمطهرات الطبيعيه على صفات الفقس و العد البكتيرى

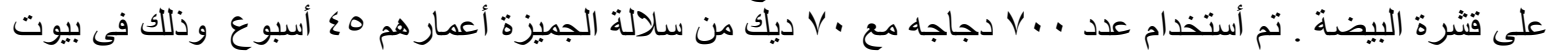

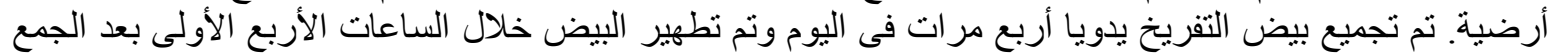

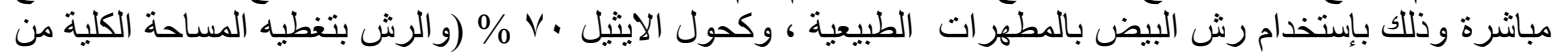

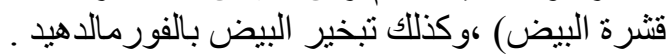

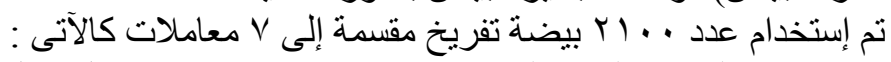

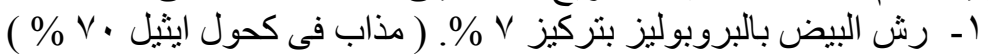

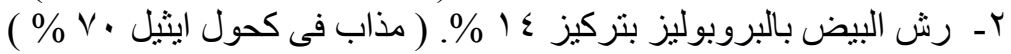

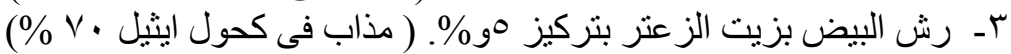

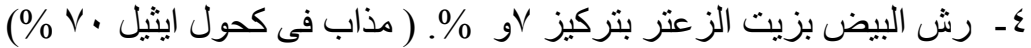

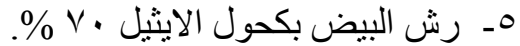

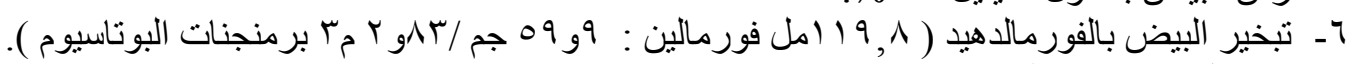

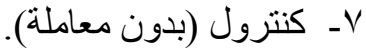

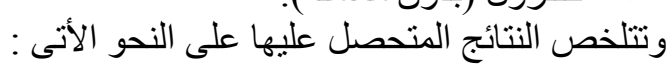

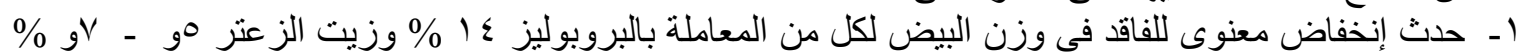

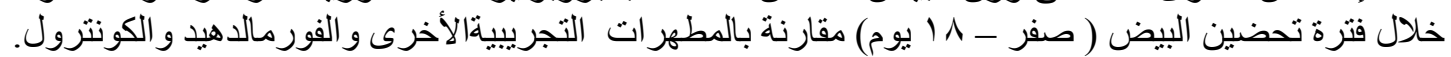

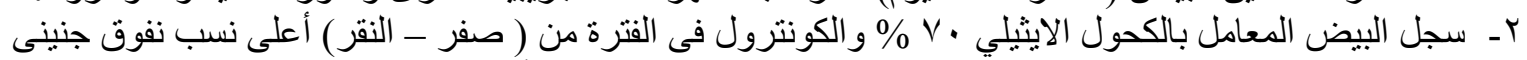

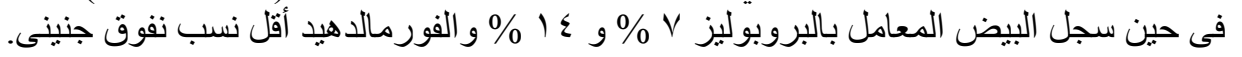

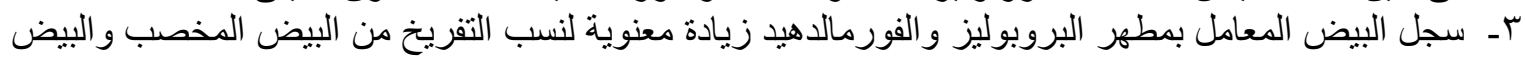

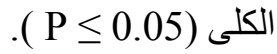

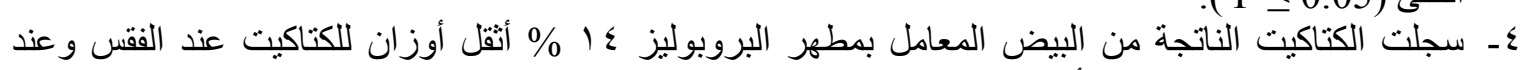

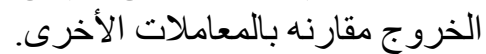

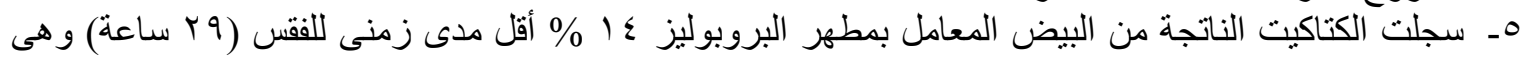
الفترة بين أول وأخر فقس للكتاكيت ( أى بين أقصر وأطول زمن للفقس ) بينما سجلت الكتاكيت الناتجة من

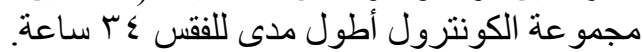

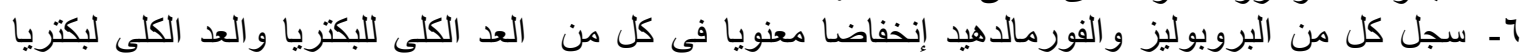

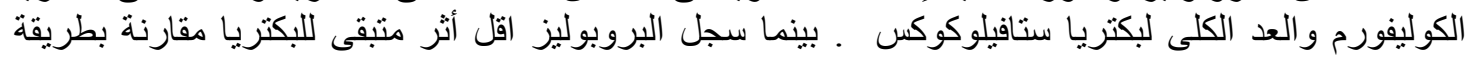
التبخير بالفورمالدهيد

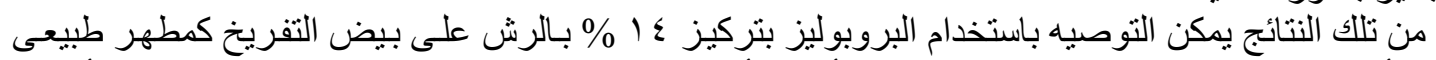

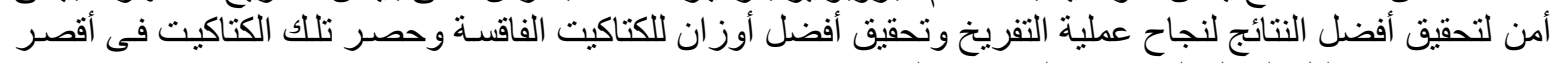

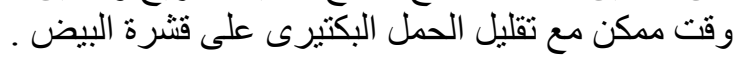

